\title{
Paenibacillus sp., as a promising candidate for development of a novel technology of inoculant production
}

\author{
N. O. Kozyrovska, V. V. Negrutska, M. V. Kovalchuk, T. N. Voznyuk \\ Institute of Molecular Biology and Genetics of the National Academy of Sciences \\ 150 Zabolotnoho str., 03143 Kyiv, Ukraine \\ E. mail: kozyr@imbg.org.ua
}

\begin{abstract}
A bacterial strain IMBG156 producing exopolysaccharide (EPS) was isolated from siliceous rock and identified as a Paenibacillus species by partial sequencing its 16 S rDNA. Paenibacillus sp. IMBGI56 was used in a novel technology for inoculant production based on co-cultivating this bacterium with any bacterium of choice. Paenibacillus sp. provides in situ the bacterial cells of the inoculant with EPS, a carrier, and most likely with a source of carbon and energy. The partner bacterium designates a type of inoculant (biopesticide or biofertiliser). The strain IMBGIS6 does not destroy the signaling system of Gram-negative partners, based on acylated homoserine lactones, stimulates plant growth, and is rather competitive in the plant rhizosphere and soil. $A$ prototype of the inoculant based on dual-culture Paenibacillus sp. IMBGI56 - Pseudomonas sp. IMBG163 exhibits a noticeably longer shelf life than monoculture of Pseudomonas sp. IMBG163.
\end{abstract}

Key words: exopolysaccharide, inoculant, partner bacteria.

Introduction. The increasing concern on agrochemicals hazard to health and economical problems have promoted fundamental research in the area of alternative agriculture and in search for new agrobiotechnologies. Recently, tremendous efforts have been invested in studies of molecular mechanisms of plant defense $[1-3]$.

Defense-signaling components have been discovered, and new, effective and sustainable alternatives to pesticides proposed. However, at the present time a sustainable strategy of crop defense still relies on usage of microbial biological agents able to induce system resistance in crop plants. The microbial inoculants based on the competitive, beneficial for the plant bacteria are considered as a reasonable alternative to agrochemicals $[4,5]$. It is critical for the $\begin{array}{llllllll}\text { (C) N. } & \text { o. } & \text { KOZYROVSKA, } & \text { V. } & \text { v. NEGRUTSKA, } & \text { M. } & \text { V. KOVALCHUK, } \\ \text { T. } & \text { N. } & \text { VOZNYUK, } 2005 & & & & \end{array}$ inoculant development that the inoculant product was in a formulation not only to deliver an adequate bacterial population but also to have enough product shelf life. Nowadays, the practical formulations are in use to prolong survival of Gram-negative bacteria [6-11], however, the usage of both mineral and organic carriers for bacteria makes inoculants more expensive. In our previous research we used the exopolysaccharide (EPS) mucilan produced by $B$. mucilaginosus $\mathrm{B}-4901$ as an inexpensive carrier in the series of inoculants KLEPS (KLityna (a cell, Ukr.) and EPS) to prolong Gram-negative bacteria survival [12]. The inoculants enhanced crop production on poor soils and exhibited enough shelf life. In spite of advantages, the technology of KLEPS development needed a separate stage of EPS manufacture, which complicated the procedure and raised the price of the inoculant. The objectives of this study were to isolate slime-producing bacteria, following the idea to use 
EPS as a carrier for inoculant development, and to simplify the two-stage technology of inoculant manufacture.

Materials and Methods. Bacterial strains. The microorganisms used in this work were either from our Institute collection (Paenibacillus sp. IMBG156, Klebsiella oxytoca IMBG26, Rif ${ }^{f}$, Pseudomonas sp. IMBG163, Pseudomonas sp. IMBG168, $P$. aureofaciens IMBG288, Agrobacterium sp. IMBG260, $P$. syringae pv. syringae IMБГ295, Xanthomonas axonopodis pv. phaseoli ІМБГ293) or kindly provided from other collections: $P$. fluorescens 13525 from ATCC; Pseudomonas sp. AP33 from A. Perebityuk (Institute of Cytology and Genetics of Belarus Academy of Sciences, Minsk); Pantoea agglomerans IMV56 and Erwinia carotovora subsp. atroceptica IMB9027 from R. Gvozdyak (Institute of Microbiology and Virology of NASU, Kyiv); Agrobacterium tumefaciens A136, A. tumefaciens NT1 (pTiC58 $\Delta \mathrm{accR}$ ) and $A$. tumefaciens NT1 from L. Halda-Alija (Mississippi University).

Culture conditions. The media for bacterial growth were: KB [13] and L.B [14] used for all strains of bacteria, except for Paenibacillus sp. being cultured in the medium MZ [12]. Zeolite $(10 \mathrm{~g} / \mathrm{l})$ was added to $\mathrm{LB}$ when needed.

Determination of EPS content. Cells of a two-day culture were centrifuged at $10,000 \mathrm{~g}$ for $30 \mathrm{~min}$, EPS was extracted from supernatant by $2 \mathrm{v}$ of ethanol and dried at $37{ }^{\circ} \mathrm{C}$ until stable weight was obtained.

Bacteria isolation procedures were performed using the samples of zeolite collected from Sokyrnytzya (Transkarpatian region) and fragments of silica rocks originated from Khmelnitsky region. In separate experiments $1 \mathrm{~g}$ of zeolite or silica rocks (fraction of $5 \mathrm{~mm}$ ) was incubated in $\mathrm{MZ}$ for $48 \mathrm{~h}$ at $30^{\circ} \mathrm{C}$. The accumulating cultures were diluted serially and spread on selective $M Z$ medium. Slime colonies were collected, bacteria were purified, and identified according to N. Krasilnikov [15].

Total DNA isolation was performed as recommended in [16].

Amplification, purification, and analysis of $16 \mathrm{~S}$ rDNA. PCR primers pair of $\mathrm{pA}(8-27)$ and $\mathrm{pH}$ (1542-1523) described in [17] was used for identification of the rrn (16S rRNA) gene, and specific sequences of two selected isolates were detected at the annealing temperature of $52{ }^{\circ} \mathrm{C}$ and the standard concentration of $\mathrm{MgCl}_{2}(1.5 \mathrm{mM})$. The reaction was performed with 25 pmol of each primer («Sigma», USA), $50 \mu \mathrm{M}$ dNTP-mix, $2 \mathrm{U}$ of Taq-DNA-poly- merase (both reagents from «Fermentas», Lithuania). Amplification was carried out in ALF thermal cycler («Pharmacia», Sweden). Initial denaturation was performed at $98{ }^{\circ} \mathrm{C}$ for $3 \mathrm{~min}$, then Taq-DNA-polymerase was added. The thermal profile involved 28 cycles of penetration temperature of $93{ }^{\circ} \mathrm{C}$ for $30 \mathrm{~s}$, primer annealing at $52{ }^{\circ} \mathrm{C}$ for $30 \mathrm{~s}$ and $72{ }^{\circ} \mathrm{C}$ for $1 \mathrm{~min}$. Amplicons were checked on a $2.0 \%$ agarose gel. Purification of amplicons was performed with UltraClean $^{\text {TM }}$ PCR Clean-up ${ }^{\mathrm{TM}}$ Kit (MoBio Laboratories Inc., USA). Analysis of PCR products performed by Blast $\mathrm{N}$ search program (NCBI, http://www.ncbi.nlm.nih.gov). A phylogenetic tree was constructed by the program ClustalW 1.83 (http://www.genebee.msu.su/genebee.html).

Co-cultivating of partners was performed in $M Z$. After $30 \mathrm{~h}$ of co-cultivating, the serial dilutions were made for evaluation of population size. The partner cultures were detected on LB or KB agar, Paenibacillus sp. - on MZ plates.

Assay for production of signaling molecules. Bacterial strains (separately and in pairs with Paenibacillus sp.) were tested in cross-feeding assays for acylated homoserine lactones (AHLs), using the indicator strain $A$. tumefaciens $\mathrm{Al} 36$ as recommended in [18].

Antibacterial activity was tested in vitro on Petri dishes by the standard agar-diffusion assay, using two layer agar with the upper layer of an indicator culture soft agar $(0.4 \%)$.

Detection of the acetylene reductase (nitrogenase) activity (ARA) was performed according to [19]. The ARA of $K$. oxytoca IMBG26 was detected with the gas chromatograph Tzvet (Cheh Republic) in $14 \mathrm{ml}$ flasks where the bacterial culture was grown in an $\mathrm{N}$-free medium supplemented with sucrose or EPS (final content 1.5 and $1.0 \%$, respectively) in the presence of $10 \%$ acetylene within $16 \mathrm{~h}$ at $28{ }^{\circ} \mathrm{C}$.

Plant growth conditions, bacteria inoculation and re-isolation. Ten wheat germinated seeds were inoculated with a washed overnight monoculture, a dual culture or a suspension of bacterial strains mixed in equal proportions $\left(10^{6}\right.$ colony forming units, $\mathrm{CFU} / \mathrm{ml}$ ) and placed in zeolite (Sokyrnytzya deposit). Control plants were left non-inoculated. The plants were maintained under natural light at $20^{\circ} \mathrm{C}$ in a growth chamber. The plants were watered once per two days. At the end of the experiment (14 days after inoculation) all plants were harvested and external root colonization was examined. Root sections of $100 \mathrm{mg}$ 
Biometrical data of effects of wheat seed inoculation by Paenibacillus sp. IMBGIS6 on growth parameters of 30-day seedlings

\begin{tabular}{l|c|c|c}
\hline \multicolumn{1}{c|}{ Variant } & Dry weight of a single plant, & Shoot height, cm & Roat leagth, cm \\
\hline & $0,036 \pm 0,008 \mathrm{a}$ & $44,856 \pm 1,212 \mathrm{~b}$ & $10,960 \pm 0,460 \mathrm{a}$ \\
Paenibacillus sp. IMBG156 & $0,044 \pm 0,002 \mathrm{~b}$ & $44,316 \pm 1,036 \mathrm{~b}$ & $11,080 \pm 0,457 \mathrm{~b}$ \\
Pseudomonas sp. IMBG163 & $0,045 \pm 0,003 \mathrm{~b}$ & $45,173 \pm 1,334 \mathrm{~b}$ & $11,665 \pm 0,689 \mathrm{~b}$ \\
Pseudomonas sp. IMBG163 and & $0,035 \pm 0,002 \mathrm{a}$ & $40,466 \pm 1,003 \mathrm{a}$ & $9,215 \pm 0,434 \mathrm{a}$
\end{tabular}

$\mathrm{N}$ o $\mathrm{t}$ e. Error represents standard deviation. Treatment is different from the control at $\mathrm{p}=0.05$ as determined by Student's $t$-test. Vaives followed by the same letter in a column are not significantly different.

were vortexed in $0.9 \% \mathrm{NaCl}$, and serial dilutions were plated on selective media LB, KB, MZ supplemented with rifampicin $(50 \mu \mathrm{g} / \mathrm{ml})$ when needed to discriminate between bacteria.

Statistical analysis of results. The data on biometrical parameters of wheat and bacteria survival are means from three replications. Statistical analysis was performed using SigmaPlot 8.0 software. Standard deviations were calculated for each data point.

Nucleotide sequence accession number. The sequence generated in this study has been deposited in the GenBank database under accession number AY645946.

Results and Discussion. Phenotypic characteristics. Two isolates (from zeolite and silica rock, designed IMBG156 and IMBG157) were characterized as aerobic Gram-positive rods of $(0.2-0.5) \cdot 2.0 \mu \mathrm{m}$ which formed spores of $0.5-0.7 \mu \mathrm{m}$. The spore position was preferentially central but terminal location was rarely observed. The optimal temperature of growth was $28{ }^{\circ} \mathrm{C}$, but they grew well in a range of $10-45^{\circ} \mathrm{C}$. On the agar $\mathrm{MZ}$ medium they created transparent slime colonies of $10.0-13.0 \mathrm{~mm}$ diameter and produced $10.0-13.0 \mathrm{~g}$ EPS per 11 of liquid medium. The isolates consumed carbohydrates, generated acids, and did not utilize amino acids as $\mathrm{C}$ and $\mathrm{N}$ sources. Bacteria hydrolyzed starch and could not grow anaerobically with nitrate as a respiratory substrate. We did not manage to determine the taxonomic position of the isolates with Bergy's determinative manual. To clarify their systematic position, it was practical to analyze the phylogenetic marker gene, $r r n$, encoding RNA of small subunit of ribosome (16S).

Analysis of the 16S rDNA amplicon. The 16S rDNA amplicons were obtained from IMBG156 of $1500 \mathrm{bp}$ in PCR, and a sequence of $621 \mathrm{bp}$ was deciphered and aligned with the most closely related bacterial sequences. The sequence shared $97 \%$ similarity to the deposited sequence for Paenibacillus velasolus. In a phylogenetic tree based on sequencing data this isolate clustered with $P$. velasolus, however, more efforts were needed to prove or disprove rela-

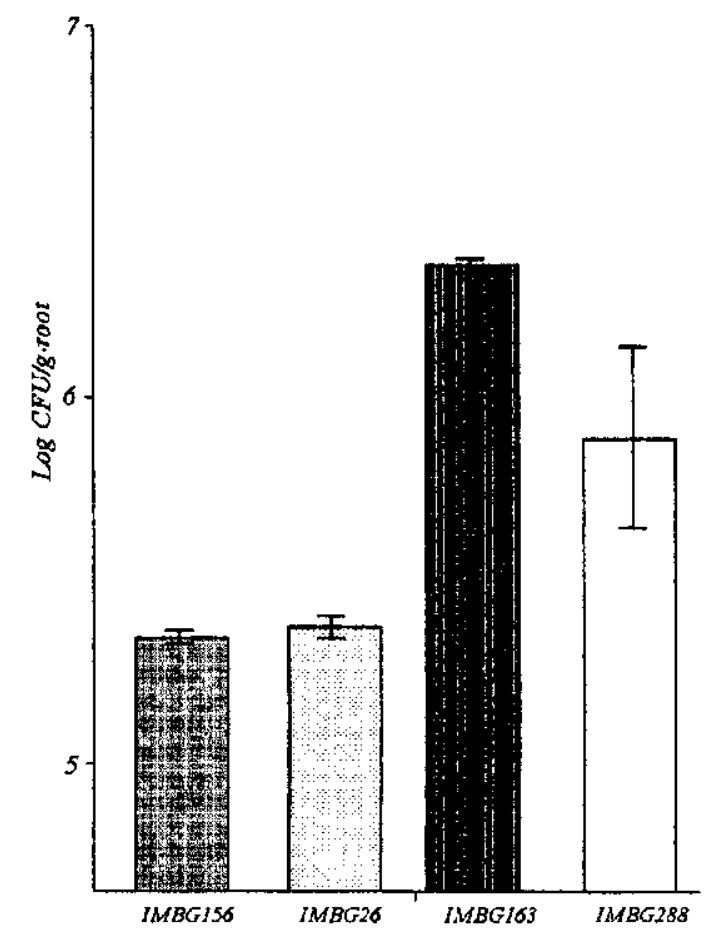

Fig 1. Average size of populations of bacterial strains associated with wheat roots: two weeks after inoculated seed planting

tedness of the isolate to $P$. velasolus, and in this study we did not use a species name.

Effects of the bacterium on growth of wheat and survival in the plant rhizosphere. Relation to the plant of the assistant bacterium planned for the inoculant development should be at minimum neutral, but not antagonistic. The tests showed that strain IMBG156 
Table 2

Co-cultivating Gram-negative bacteria with Paenibacillus sp. IMBGI56

\begin{tabular}{|c|c|c|}
\hline Vartant & $\begin{array}{l}\text { Concentration of cells in the mixed culture after } \\
\text { the } 30 \mathrm{~b} \text {-tocubation period, CFu/mi }\end{array}$ & $\begin{array}{l}\text { Conceniration of cells in the monoculture after the } \\
30 \mathrm{~h} \text {-incuballon pertod, CFU/ml }\end{array}$ \\
\hline K. oxytoca IMBG26 & $1.4 \pm 0.05 \mathrm{E}+9$ & $6.8 \pm 0.04 E+8$ \\
\hline Pseudomonas sp. AP33 & $6.5 \pm 0.09 \mathrm{E}+9$ & $9.5 \pm 0.41 \mathrm{E}+8$ \\
\hline P. fluorescens ATCC 13525 & $1.6 \pm 0.07 \mathrm{E}+10$ & $9.3 \pm 0.02 \mathrm{E}+8$ \\
\hline P. aureofaciens IMBG288 & $3.7 \pm 0.07 E+9$ & $5.9 \pm 0.08 \mathrm{E}+8$ \\
\hline Pseudomonas sp. IMBG163 & $2.5 \pm 0.09 \mathrm{E}+9$ & $6.9 \pm 0.08 \mathrm{E}+8$. \\
\hline P. agglomerans IMV56 & $5.0 \pm 0.08 \mathrm{E}+9$ & $6.3 \pm 0.29 \mathrm{E}+8$ \\
\hline Agrobacterium sp. IMBG260 & $3.7 \pm 0.07 \mathrm{E}+9$ & $1.5 \pm 0.50 \mathrm{E}+8$ \\
\hline Paenibacillus sp. IMBG156 & - & $2.4 \pm 0.03 E+8$ \\
\hline
\end{tabular}

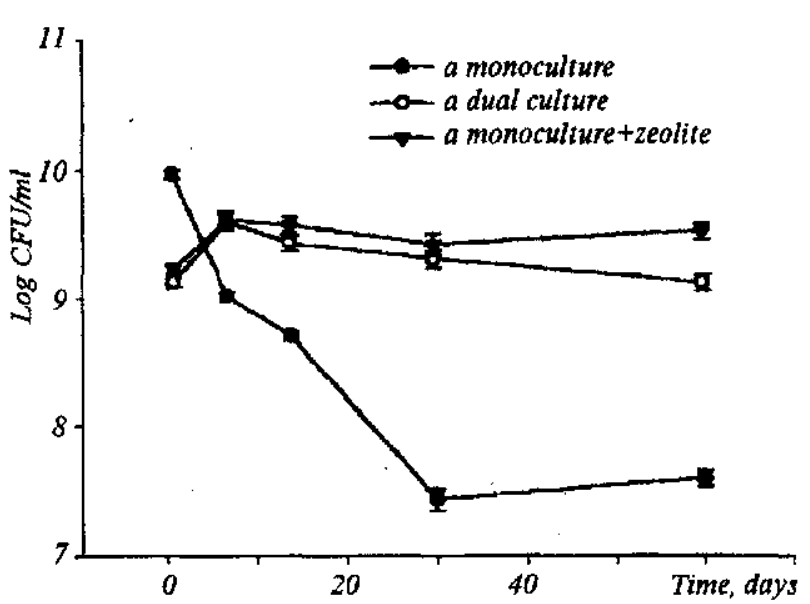

Fig. 2. Dynamics of survival of Pseudomonas sp. MMBG163 in dependence on culture conditions

did not cause a phytotoxic effect and increased wheat shoot height as shown in Table 1. Being applied together with Pseudomonas sp. IMBG163 for seed inoculation, it promoted plant growth more efficiently. In the rhizosphere of wheat inoculated by a rationally assembled consortium of plant growth promoting rhizobacteria (Pseudomonas sp. IMBG163, $P$. aureofaciens IMBG288, $K$. oxytoca IMBG26), the strain IMBG156 was quite competitive on background of beneficial bacteria (Fig. 1).

Co-cultivation of Paenibacillus sp. IMBG156 with bacteria of interest. With the idea to keep bacteria alive in the gel produced by bacteria within cocultivation, Paenibacillus sp. and chosen Gram-negative bacteria were cultured by pairs. The results of experiments on co-cultivating showed practically the absence of restrictions in picking up partners for
Paenibacillus sp. (Table 2). The partners gained a population size of $\log 9-10 \mathrm{CFU} / \mathrm{ml}$. The critical factors in the one-step procedure of prototype inoculant manufacture were the size of population of a strain that determined a sort of inoculant, and also the concentration of EPS produced by Paenibacillus sp. In the case of co-cultivating IMBG156 together with $K$. axytoca IMBG26 or Pseudomonas sp. IMBG163, the culture gel contained $1.4 \pm 0.05 E+9$ or $2.5 \pm 0.09 \mathrm{E}+9 \mathrm{CFU} / \mathrm{ml}$ of a bacterium-partner, respectively, and not less than $20.0 \mathrm{~g} / 1$ of EPS.

A term of the inoculant shelf life is important when the inoculant is based on Gram-negative bacteria. We showed that survival of Pseudomonas sp. IMBG163 was prolonged in the dual culture with Paenibacillus sp. in comparison with the monoculture (Fig. 2). A better survival of IMBG163 was also observed in a minimal medium supplemented with zeolite. The results showed that the strain IMBG163 preserved the population size at the level of log $9 \mathrm{CFU} / \mathrm{ml}$ in both dual culture and monoculture grown in the presence of zeolite within 2 months. On the contrary, the population size of IMBG163 declined from $\log 10$ to $\log 7 \mathrm{CFU} / \mathrm{ml}$ without coinoculation by Paenibacillus sp. IMBG156 or addition of the mineral to the medium. This clearly demonstrated that both Paenibacillus and zeolite supported survival of Pseudomonas sp. IMBG163. K. oxytoca IMBG26 was able to grow and reduce acetylene (518 $\mathrm{nM} \mathrm{C}_{2} \mathrm{H}_{4} / \mathrm{h}$ flask) in the nitrogen-free medium where $1.0 \%$ EPS (derived from Paenibacillus sp. IMBG156) was used as a carbon source, and this suggested that EPS produced by Paenibacillus had the potential to support growth and activity of the partner. 
Table 3

Antibacterial activity of dual and monocultures of Pseudomonas spp. in vitro

\begin{tabular}{l|c|c|c}
\hline \multicolumn{1}{c|}{ Inoculant } & I* & II & III \\
\hline Pseudomonas sp. IMBG163 & $4^{* *}$ & 3 & 4 \\
Pseudomonas sp. IMBG163 + Paenibacillus sp. IMBG156 & 4 & 3 & 4 \\
Pseudomonas sp. IMBG168 & 4 & 3 & 4 \\
Pseudomonas sp. IMBG168 + Paenibacillus sp. IMBG156 & 4 & 3 & 4 \\
P. aureofaciens IMBG288 & 2 & 2 & 3 \\
P. aureofaciens IMBG288 + Paenibacillus sp. IMBG156 & 2 & 2 & 3 \\
\hline
\end{tabular}

*Indicator phytopathogenic bacteria: I - P. syringae pv. syringae IMBG295; II - Erwinia carotovora subsp. atroceptica IMB9027; III Xanthomonas axonopodis pv. phaseoli IMBG293; **diameter of zone of suppression of indicator bacteria (mm): $2-10.0-20.0 ; 3-$ $21.0-30.0 ; 4-31.0$.

Detection of antibacterial activity in dual cultures. Signaling systems play a role in bacteria-bacteria and plant-bacteria communications [20]. Antibacterial activity of some pseudomonads is controlled with AHLs [21, 22 ]. It is well known that Gram-positive bacteria are able to destroy AHLs of Gram-negative neighbors [23]. To compose dual bacterial pairs, it is important to know that quorum signaling is not impaired by co-cultivation. Bacteria used in experiments on cocultivation were tested in cross-feeding assays for $\mathrm{AHL}_{4-14}$ detection earlier [24]. Few of them produced AHLs (Pseudomonas sp. IMBG163, Pseudomonas sp. IMBG168 and $P$. auerofaciens IMBG288), and no difference was observed between mono- and dual Pseudomonas-Paenibacillus cultures with respect to AHL production. The results represented in Table 3 showed inhibition of pathogenic bacteria by both monocultures of pseudomonads and appropriate dual Pseudomonas-Paenibacillus cultures. This may mean that strain Paenibacillus sp. IMBG156 did not impair AHLs produced by a partner and indirectly demonstrated integrity of AHLs in dual cultures.

Paenibacillus sp. IMBG156 has been selected as a bacterium-nurse for the dual-culture technology of inoculant development, first of all, due to production of large amounts of EPS. The strain IMBG156 provided the living cells of a bacterium-partner, the second species of two-component consortium, with a carbon source and apparently caused better survival of the latter. In this study IMBG156 displayed commensal interactions in the pairs with other bacterial strains and synergistic positive impact on the plant. These results are consistent with those obtained for other bacteria acting synergistically on the plant development $[25,26]$. IMBG156 was quite competitive in the plant rhizosphere bacterial community and in the soil, in contrast to the known data on the gradual replacement of Paenibacillus by Pseudomonas [27]. These additional beneficial features make the strain rather promising for application for seed inoculation in programs of plant health care and soil remediation in company with biocontrol bacteria.

The inoculants, containing both Paenibacillus sp. IMBG156 and a partner bacterium, can be stored for a relatively long period of time in the presence of large amounts of EPS produced in situ without preservatives and conventional carriers. This finding is based on a concept of keeping bacteria alive under storage of the dual culture in a gel and may be explained, first of all, by the fact that growing any Gram-negative bacterium with Paenibacillus sp. IMBG156 results in stimulation of EPS production which can serve both as a carbon and energy source for the bacterium-partner. In case when EPS serves as a carrier, the organisms appear to establish structured populations where cells are not aggregated. Under this condition the bacteria are positioned in a heterogeneous environment with gradients of nutrients and waste products as a consequence of diffusion and mass transport processes, and it is therefore to be expected that this heterogeneity is reflected in the physiology of the individual cells and better survival. EPS keeps up water and nutritional regime, and therefore bacterial cells are physiologically active under storage, in contrast to a dry KLEPS formulation where bacteria were dormant. The dual-culture technology based on co-cultivating the bacterium Paenibacillus sp. IMBG156 and any bacterium of choice is simpler and less expensive compared to the previous technology [12]. 
Acknowledgements. We are grateful to Prof. B. Lugtenberg (Leiden University) for providing sequencing data of the rrn gene of Paenibacillus sp. IMBG156 and to Prof. Diethelm Kleiner for critical reading of the manuscript. This work partially supported by Ukrainian Branch of World Wide Laboratory, subcontract $\mathrm{N}$ 901-02-5281-5700-WLU.

\section{Н. О. Козировська, В. В. Негруцька, М. В. Ковальцук,} T. М. Вознюк

Paenibacillus sp. - перспективна бактерія для створення технології виробництва бакпрепаратів для рослин

Резкме

ШІам бактерій IMBG156, який продукує екзополісахарид (ЕПC), виділено з силікатної породи та ідентифіковано як Paenibacillus sp. на основі визнацення первинної нуклеотидноі послідовності $16 S$ рдНК. Paenibacillus sp. IMBG156 використано у технологіï виробництва міхробних препаратів, яка базутьсл на спільному культивуванні цієї бактерії та бактеріі за вибором. Paenibacillus sp. постачас in situ бактерійкі клітини носієм (ЕПC) та, найвірогідніше, є джерелом вуглецю і енергї. Бактерія-партнер визначае тип препарату (біодо6риво, біопестицид). Ш Мам IMBG 156 не пошкодхує сигнальноі системи грамнегативних бактерій-партнерів, яка грунтує ться на ацильованих гомосеринлахтонах, стимулюе ріст рослини $і \epsilon$ доволі конкурентною у ризосфері. у демонстраційному препараті, створеному на основі бактерій-партнерів Paenibacillus sp. IMBG156-Pseudomonas sp. IMBG163, dosue зберігасться необхідний титр бактерій, ніж у монокультурі Pseudomonas sp. IMBG163.

Ключові слова: екзополісахариди, бакпрепарат, бактерііпартнери

Н. А. Козыровская, В. В. Негруцкая, М. В. Ковальцук, T. H. Вознюк

Paenibacillus sp. - перспективная бактерия для создания технологии производства бакпрепаратов для растений

Резюме

IIтамм бактерии IMBGI56, продуцируючщй экзополисахарид (ЭПС), выделен из силихатной породы. Он идентифицирован как Paenibacillus sp. на основе определения первинной нуклеотидной последовательности $16 \mathrm{~S}$ рДHK. Paenibacillus sp. IMBG 156 использован 6 технологии производства михрабиолоzических препаратов, основанной на совместном культивироөании этой и өыбранной бактерий Paenibacillus sp. снабхает in situ клетки бактерий носителем (ЭПС) и яеляется, наиболее вероятно, истонником углерода и энераи. Бактерия-партнер определяет тип препарата (биоудобрение, биопестицид). HІтам IMBGI56 не повреждает сигнальной системы граммотрицательных бактерий-партнеров, которая основывается на ащилированных гомосеринлактонах, стимулирует рост растеншй и яеляется достаточно конкурентоспособной в ризосфере. В демонстрационном препарате, созданном на базе Gaxmepuй-napmнеров Paenibacillus sp. IMBG156-Pseudomonas sp. IMBGI63, дольше сохраняется необходимый титр бактерий, чем в монокультуре Pseudomonas sp. IMBGI63.

Клюиевые слова: экзополисахариды, бакпрепарат, бактериипартнеры.

\section{REFERENCES}

1. Veronese $P_{1}$, Ruiz M. T., Coca M. A., Hernandez-Lopez A., Lee H., Jbeas J., Damsz B., Pardo J. M., Hasegawa P. M. Bressan $R$. A., Narasimhan $M$. $L$. In defense against pathogens. Both plant sentinels and foot soldiers need to know the enemy // Plant Physiol.-2003:-131.-P. 1580-1590.

2. Zeidler D., Zahringer U., Gerber I., Dubery I., Hartung T., Bors W., Hutzler $P$. Innate immunity in Arabidopsis thaliana: Lipopolysaccharides activate nitric oxide synthase (NOS) and induce defence genes // Proc. Nat. Acad. Sci. USA.-2004.101.-P. $15811-15816$.

3. Cui J., Bahrami A. K., Pringle E. J., Hernandez-Guzman G., Bender C. L. Pierce N. E., Ausubel F. M. Pseudomonas syringae manipulates systemic plant defenses against pathogens and herbivores // Proc. Nat. Acad. Sci. USA.-2005.-102.P. $1791-1796$.

4. Thomashow $L$. S., Weller D. M. Current concepts in the use of introduced bacteria for biological disease control: mechanisms and antifungal metabolites // Plant-microbe interactions / Eds G. Stacey, N. T. Keen.-New York: Chapman \& Hall, 1996. - Vol. 1.-P. 187-235.

5. Emmert $E$, Handelsman $J$. Biocontrol of plant disease: a (gram-) positive perspective // FEMS Microbiol. Lett.1996. -171.-P. 1-9.

6. Ocumpaugh $W$. R., Smith G. $R$. Granular inoculum enhances establishment and forage production of arrowleaf clover // J. Prod. Agric.-1991.-4.-P. 219-224.

7. Olsen P. E., Rice W. A., Bordeleau L M., Demidoff A. H., Collins $M . M$. Levels and identities of nonrhizobial microorganisms found in commercial legume inoculant made with nonsterile peat carrier // Can. J. Microbiol. $-1996 .-42 .-$ P. $72-75$

8. Walter J. F., Paau A. S. Microbial inoculant production and formulation // Soil Microbial Ecology: Applications in Agricultural and Environmental Management / Eds F. B. Metting, Jr. - New York: Marcel Dekker, Inc., 1997.-P. 579-594.

9. Manjula $K$, Pogile A. $R$. Chitin-supplemented formulations improve biocontrol and plant growth promoting efficiency of Bacillus subtilis AF $1 / /$ Can. J. Microbiol.-2001.-47.P. 618-625.

10. Russo A., Basaglia M., Tola E., Casella S. Survival, root colonisation and biocontrol capacities of Pseudomonas fluores cens F113 LacZY in dry alginate microbeads // J. Ind. Microbiol. Biotechnol.-2001.-27.-P. 337-342.

11. Temprano F. J., Albareda M., Camach M., Daza A., Santamaria C., Rodrigues-Navarro $D$. N. Survival of several Rhizobium/Bradyrhizobium strains on different inoculant formulations and inoculated seeds // Int. Microbiol._2002.-5.P. $81-86$.

12. Kozyrovska N., Kovtunovych G., Gromasova O., Kuharchuk $P$., Kordyum $V$. Novel inoculants for an environmentallyfriendly crop production $/ /$ Resources, Conservation and Recycling.-1996.-18.-P. 79-85.

13. King $E$. $O$., Ward $M$. K, Raney $D$. $E$. Two simple media for the demonstration of pyocyanin and fluorescin // J. Lab. Clin. Med.-1954.-44.-P. 301-307.

14. Миллер Д. Эксперименты в молекулярной генетике // Под ред. С. И. Алиханяна.-М.: Мир, 1976.-430 с.

15. Krasilnikov $N$. A. Determinative mannual for bacteria and actinomycetes.-Moscow: Ed. Acad. Sci. USSR, 1949.-176 p.

16. Sambrook J., Fritsch E. F., Maniatis T. Molecular cloning: a laboratory manual.-New York: Cold Spring Harbor Lab. press, $1989 .-472 \mathrm{p}$. 
17. Edwards U., Rogal T., Bloecker M., Boettger E. C. Isolation and direct complete nucleotide determination of entire genes. Characterization of a gene coding for $16 \mathrm{~S}$ ribosomal RNA // Nucl. Acids Res.-1989.-17.-P. 7843-7853.

18. Fuqua $C$., Winans $S$. C. Conserved cis-acting promoter elements are required for density-dependent transcription of Agrobacterium tumefaciens conjugal transfer genes $/ / \mathbf{J}$. Bacteriol.-1 1996.-178.-P. 435-440.

19. Postgate $J . R$. The acetylene reduction test for nitrogen fixation // Methods in microbiology / Eds J. R. Norris, D. W. Ribbons.-London; New-York: Acad. press, 1972.-P. 343356.

20. Fuqua C., Winans S. C., Greenberg E. P. Quorum sensing in bacteria: the LuxR-LuxI family of cell density-responsive transcriptional regulators // J. Bacteriol.-1994.-176.P. 269-275.

21. Chancey S. T., Wood D. W., Pierson, III, LS. Two-component transcriptional regulation of $\mathrm{N}$-acyl-homoserine lactone production in Pseudomonas aureafaciens // Appl. Environ. Microbiol. -1999.-65.-P. 2294-2299.

22. Delany 1., Sheehan M. M., Fenton A., Bardin S., Aarons S., $O^{\prime}$ Gara $F$. Regulation of production of the antifungal metabolite 2.4-diacetylphloroglucinol in Pseudomonas fluorescens F113: genetic analysis of phlF as a transcriptional repressor // Microbiology.-2000.-146.-P. 537-546.
23. Dong Yi-Hu, Xu Jin-Ling, Li Xian-Zhen, Zhang Lian-Hui. AiiA, an enzyme that inactivates the acylhomoserine lactone quorum-sensing signal and attenuates the virulence of Erwinia carotovora // Proc. Nat. Acad. Sci. USA.-2000.-97.P. 3526-3531.

24. Kovalchuk M. V., Negrutska V. V., Kozyrovska N. O. Characteristics of pseudomonads as candidates for a novel inoculat based on the Dual technology // Agroecologichny Zhurnal (J. Agroecol.).-2004.-2.-P. 41-45.

25. Alagawadi A. R., Gaur A. C. Inoculation of Azospirillum brasilense and phosphate-solubilizing bacteria on yield of sorghum [Sorghum bicolor (L.) Moench] in dry land // Trop. Agric. - 1992.-69.-P. 347-350.

26. Bent E., Tuzun S., Chanway C. P., Enebak S. Alterations in plant growth and in root hormone levels of lodgepole pines inoculated with rhizobacteria // Can. J. Microbiol.-2001.47.-P. 793-800.

27. Molbak L. Licht T. R., Kvist T., Kroer N., Andersen S. Plasmid transfer from Pseudomonas putida to the indigenous bacteria on alfalfa sprouts: characterization, direct quantification, and in situ location of transconjugant cells // Appl. Environ. Microbiol.-2003.-69.-P. 5536-5542.

УдК 574:539

Надійшла до редакціі 25.06.04 